\title{
Safety Design Strategy for the Remote-Handled Low-Level Waste Disposal Project
}

October 2009

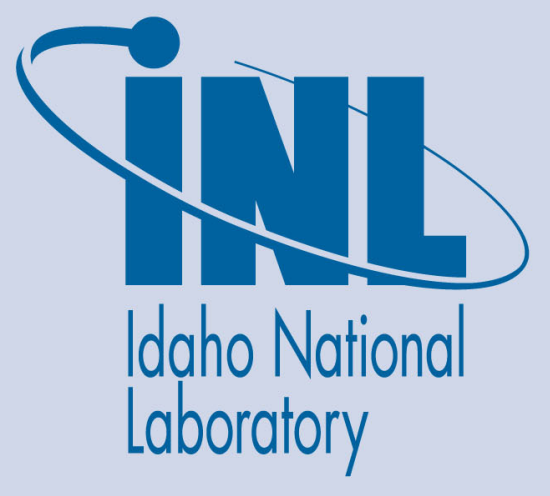

The INL is a U.S. Department of Energy National Laboratory operated by Battelle Energy Alliance 


\section{DISCLAIMER}

This information was prepared as an account of work sponsored by an agency of the U.S. Government. Neither the U.S. Government nor any agency thereof, nor any of their employees, makes any warranty, expressed or implied, or assumes any legal liability or responsibility for the accuracy, completeness, or usefulness, of any information, apparatus, product, or process disclosed, or represents that its use would not infringe privately owned rights. References herein to any specific commercial product, process, or service by trade name, trade mark, manufacturer, or otherwise, does not necessarily constitute or imply its endorsement, recommendation, or favoring by the U.S. Government or any agency thereof. The views and opinions of authors expressed herein do not necessarily state or reflect those of the U.S. Government or any agency thereof. 


\section{Safety Design Strategy for the Remote-Handled Low-Level Waste Disposal Project}

October 2009

Idaho National Laboratory

Idaho Falls, Idaho 83415

http://www.inl.gov

Prepared for the

U.S. Department of Energy

Office of Nuclear Energy

Under DOE Idaho Operations Office

Contract DE-AC07-05ID14517 



\begin{abstract}
In accordance with the requirements of U.S. Department of Energy (DOE) Order 413.3A, "Program and Project Management for the Acquisition of Capital Assets," safety must be integrated into the design process for new or major modifications to DOE Hazard Category 1, 2, and 3 nuclear facilities. The intended purpose of this requirement involves the handling of hazardous materials, both radiological and chemical, in a way that provides adequate protection to the public, workers, and the environment. Requirements provided in DOE Order 413.3A and DOE Order 420.1B, "Facility Safety," and the expectations of DOE-STD-1189-2008, "Integration of Safety into the Design Process," provide for identification of hazards early in the project and use of an integrated team approach to design safety into the facility. This safety design strategy provides the basic safety-in-design principles and concepts that will be used for the Remote-Handled Low-Level Waste Disposal Project.
\end{abstract}




\section{CONTENTS}

ABSTRACT iii

ACRONYMS vii

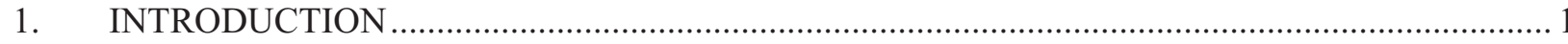

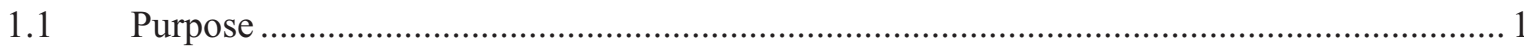

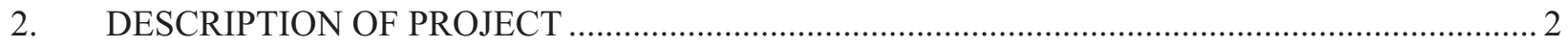

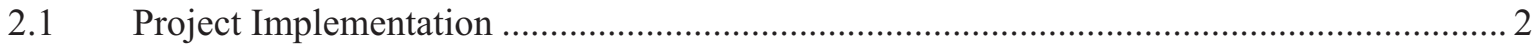

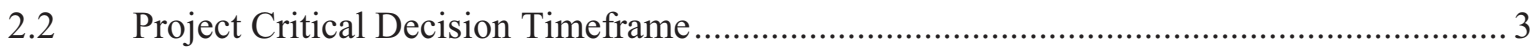

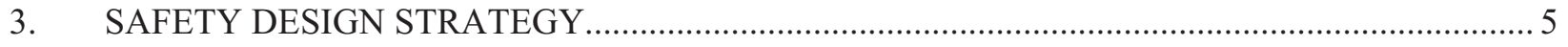

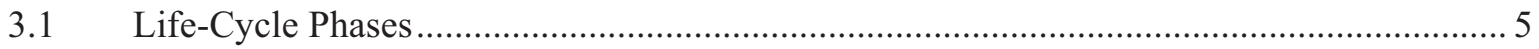

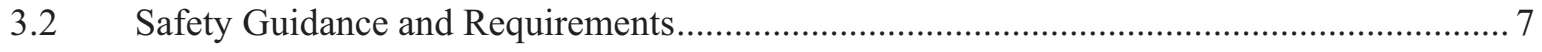

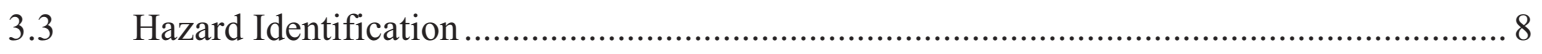

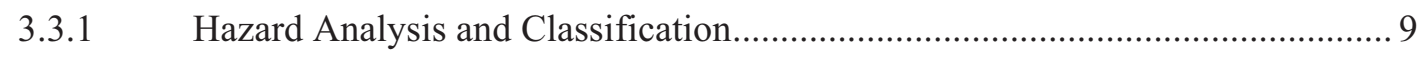

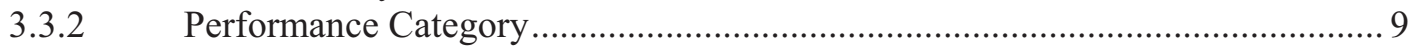

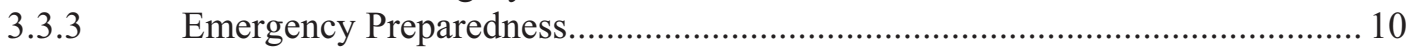

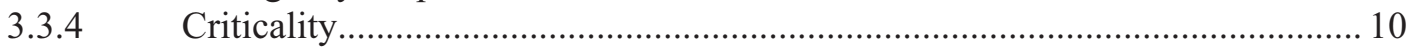

3.3.5 Facility, Structures, Systems, and Component Functions ................................ 10

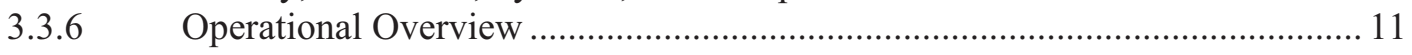

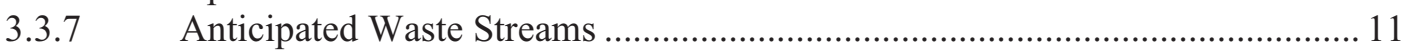

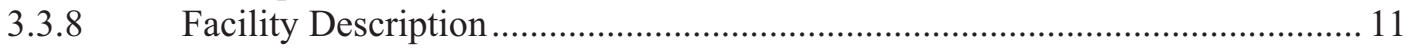

3.3.9 Identification of Primary Facility Hazards .................................................. 13

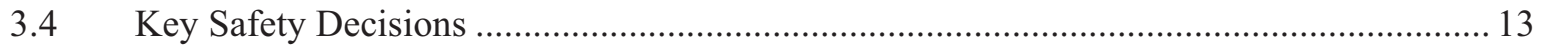

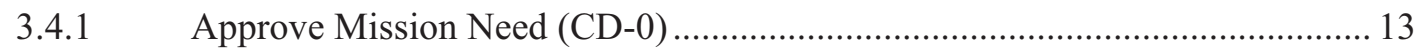

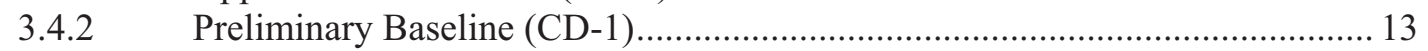

3.4.3 Approve Performance Baseline and Authorization to Execute (CD-2/3A) ...... 16

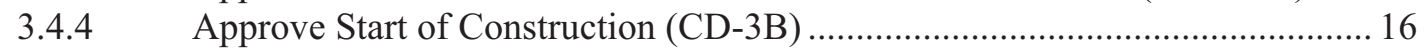

3.4.5 Approve Start of Operations (CD-4) ............................................................. 16

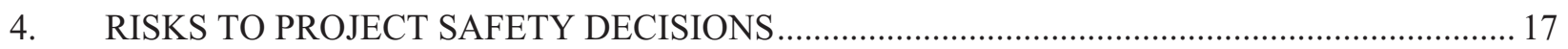

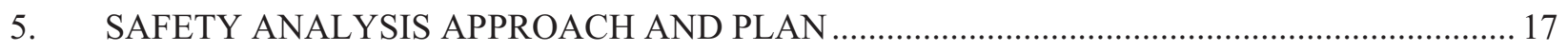

6. SAFETY DESIGN INTEGRATION TEAM - INTERFACES AND INTEGRATION ................. 18

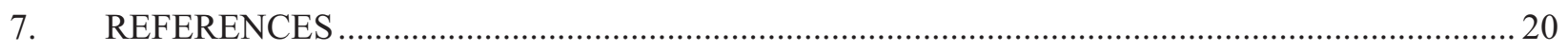




\section{FIGURES}

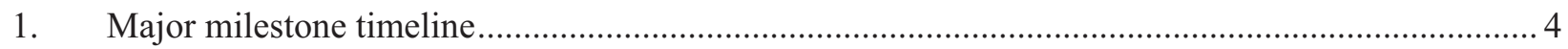

2. Project life cycle tailored to a design-build project delivery method ......................................... 6

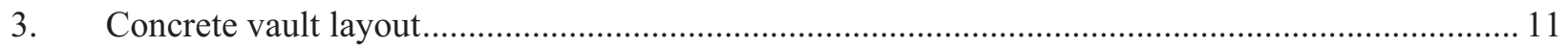

4. Proposed layout for the remote-handled low-level waste disposal facility .................................. 12

\section{TABLES}

1. Preliminary hazards identified for the remote-handled low-level waste disposal project ............... 14

2. Remote-handled low-level waste disposal project safety design integration team ........................ 19 


\section{ACRONYMS}

CERCLA Comprehensive Environmental Response, Compensation and Liability Act

CD critical decision

DOE Department of Energy

DSA documented safety analysis

FY fiscal year

INL Idaho National Laboratory

LLW low-level waste

NRF Naval Reactors Facility

PDSA preliminary documented safety analysis

RWMC Radioactive Waste Management Complex

SDA Subsurface Disposal Area

SDS safety design strategy 


\section{Safety Design Strategy for the Remote-Handled Low-Level Waste Disposal Project}

\section{INTRODUCTION}

This safety design strategy (SDS) document provides the basic safety-in-design principles and concepts that will be used for the Remote-Handled Low-Level Waste (LLW) Disposal Project at the Idaho National Laboratory (INL). In accordance with the requirements of Department of Energy (DOE) Order 413.3A, "Program and Project Management for the Acquisition of Capital Assets," safety must be integrated into the design process for new or major modifications to DOE Hazard Category (HC) 1, 2, and 3 nuclear facilities.

\subsection{Purpose}

The intended purpose of this requirement involves the handling of hazardous materials, both radiological and chemical, in a way that provides adequate protection to the public, workers, and the environment. Requirements provided in DOE Order 413.3A and DOE Order 420.1B, "Facility Safety," and the expectations of DOE-STD-1189-2008, "Integration of Safety into the Design Process," provide for identification of hazards early in the project and use of an integrated team approach to integrate safety into project planning and execution. The governing precepts are listed as follows:

- $\quad$ Ensure appropriate and reasonably conservative safety structures, systems, and components are selected early in the project designs

- Ensure project cost estimates include the costs of incorporating safety-related features into the structures, systems, and components

- Identify project risks associated with selections of safety structures, systems, and components for informed risk decision making by the project approval authorities

- Describe the major hazards anticipated in the facility and how those hazards will be addressed using safety structures, systems, and components.

The provisions of DOE-STD-1189-2008, when implemented in conjunction with DOE Order 413.3A and its guidance documents, are consistent with the core functions and guiding principles of the Integrated Safety Management System, as described in DOE Policy 450.4, "Integrated Safety Management Policy." The expectations for safety-in-design and the safety design guiding principles must be applied to these efforts to ensure that the design requirements and selection of the preferred processing and facility arrangements are performed in a way that will result in a safe design.

An SDS provides a roadmap for strategizing how important safety issues will be addressed in the design and in tailoring development of key safety documentation. This SDS document describes the overall safety strategy, key assumptions, and expected safety deliverables to be developed during the Remote-Handled LLW Disposal Project. This SDS was prepared in accordance with Section 2.3 and Appendix E of DOE-STD-1189-2008. 
This SDS is intended to be a living document with ongoing revisions as the design for the facility matures through the design process. This will ensure that all safety-related components and requirements are incorporated into facility design, properly designed and incorporated into the facility configuration, and carried through into disposal operations in accordance with DOE Order 413.3A.

It is anticipated that the eventual safety basis developed for the facility being constructed will be based on the format and content of DOE-STD-3009-94, CN 3, "Preparation Guide for U.S. Department of Energy Nonreactor Nuclear Facility Safety Analysis."

\section{DESCRIPTION OF PROJECT}

Remote-handled LLW (i.e., greater than $200 \mathrm{mR} / \mathrm{hr}$ on contact) generated at INL includes resins and activated metals. Ion-exchange resins from pool and reactor operations are generated at the Advanced Test Reactor (approximately $36 \mathrm{~m}^{3} / \mathrm{yr}$ ) and from pool operations at the Naval Reactors Facility (NRF) (approximately $8 \mathrm{~m}^{3} / \mathrm{yr}$ ). Advanced Test Reactor ion-exchange resin is generated approximately four to six times annually from reactor loop and reactor ion-exchange systems. The generation rate depends on reactor operations and varies during the years when core internal changeouts are performed. In addition, an estimated $60 \mathrm{~m}^{3}$ of activated metals are expected to be generated from new INL programs and from processing of remote-handled waste stored at the Radioactive Scrap and Waste Facility at the Materials and Fuels Complex.

As part of ongoing cleanup activities at INL, closure of the Radioactive Waste Management Complex (RWMC) is proceeding under the Comprehensive Environmental Response, Compensation, and Liability Act (CERCLA; 42 USC 9601 et seq. 1980). Disposal of remote-handled LLW in concrete disposal vaults at RWMC will continue until the facility is full or until it is closed in preparation for final remediation of the Subsurface Disposal Area (SDA) (approximately at the end of Fiscal Year [FY] 2015).

The continuing nuclear mission of INL, associated ongoing and planned operations, and Naval spent fuel activities at NRF require continued capability to appropriately dispose of remote-handled LLW. Development of a new onsite disposal facility for the disposal of INL and tenant-generated remote-handled LLW has been identified as the highest ranked alternative for providing continued, uninterrupted INL remote-handled LLW disposal capability.

\subsection{Project Implementation}

The INL Remote-Handled LLW Disposal Project will be implemented using a design-build project delivery method, wherein a single contract will be awarded for both design and construction of the new

disposal facility. This delivery method was chosen because the project has well-defined requirements that are based on current remote-handled LLW disposal operations at INL, the configuration of the disposal facility is not complex, and there is limited risk with the design and construction phases of the project.

Upfront planning and documentation will focus on further clarifying the disposal facility operating requirements based on the conceptual design and subsequent safety analyses (e.g., nuclear safety, safeguards and security, and radiological performance assessment and composite analysis) that will augment the conceptual design package in the form of a performance specification included in the design-build procurement package. The preliminary documented safety analysis (PDSA) will be prepared during this same timeframe and be included in the package that is presented at the design-build procurement stage. Sufficient information will be provided to allow prospective contractors to prepare bids or proposals but also will allow them the flexibility to implement innovative design and construction approaches, value engineering, and other cost and time-saving initiatives. The overall objective of completing the INL Remote-Handled LLW Disposal Project using a design-build approach is to reduce 
the total cost of the project and to provide uninterrupted remote-handled LLW disposal capability through a process that can be completed quicker than a traditional design-bid-build approach.

The proposed design-build method will use a standard "design-then-build" sequencing approach. This selected approach is most appropriate for this project due to the relative simplicity in design configuration and because of the primary use of the existing RWMC disposal vault configuration in the conceptual design of the new facility. By taking this approach, the safety information available for the existing RWMC facility can be directly used for the hazards evaluation and development of the applicable safety documentation. This process will allow construction personnel to provide input into the design process and allow for early initiation of procurement of long-lead items.

\subsection{Project Critical Decision Timeframe}

The critical decision (CD) timeframe for the INL Remote-Handled LLW Disposal Project is 2009 through 2015 (as shown in Figure 1). The CD milestones are identified as follows:

- CD-0, Establish Mission Need

- $\quad$ CD-1, Conceptual Design

- $\quad \mathrm{CD}-2 / 3 \mathrm{~A}$, Approve Performance Baseline and Authorization to Execute

- $\quad$ CD-3B, Approve Start of Construction

- $\quad$ CD-4, Approve Start of Operations.

The CD milestones support a FY 2015 project completion date. CD-0 approval was obtained in July of 2009. CD-1 is planned to be completed in the first quarter of FY 2010. These preliminary activities are needed to support the preparation of project documentation and to initiate procurement activities to support award of a final design-build subcontract in the second quarter of FY 2012. The project will seek approval of a tailored, combined CD-2/3A request consistent with a design-build approach. The design-build contract request for proposal will be issued following DOE approval of CD-2/3A to support contract award in the first quarter of FY 2012, with a construction completion date of the first quarter of FY 2015. Before start of construction, CD-3B will be sought based on the design-build contractor's final design. CD-4 approval will be sought by the fourth quarter of FY 2015 so that remote-handled LLW disposal capabilities will be in place before the end of FY 2015, when the current disposal capability at RWMC is planned to cease. By adopting this approval sequence, the project is appropriately aligned with DOE Order 413.3A and the execution phase will be authorized before commencing with final design and construction.

Ensuring safety using a systems engineering and integrated safety management approach is key to a successful project. This project will comply with the INL Integrated Safety Management System Program. The Integrated Safety Management System consists of the following six components:

1. Objective

2. Guiding principles

3. Core functions

4. Mechanisms

5. Responsibilities

6. Implementation. 


\title{
Project Major Milestones
}

\author{
Oct. 2015 CD-4 Approval by DOE \\ April 2015 Submit CD-4 Approval Request Package \\ Oct. 2014 Complete Construction \\ July 2012 Start Construction \\ July 2012 CD-3B Construction Readiness Approval \\ April 2012 Submit CD-3B Approval Request Package \\ April 2012 Complete Final Design \\ January 2012 Award Design-Build Contract \\ November 2011 Issue Design-Build RFP \\ October 2011 CD-2/3A Approval by DOE \\ March 2011 Submit CD-2/3A Approval Request Package \\ March 2010 CD-1 Approval by DOE/Initiate CD-2/3A \\ Dec. 2009 Submit CD-1 Approval Request Package \\ July 2009 Receive CD-0 Capital Approval//nitiate CD-1


The systems engineering approach incorporates integrated safety management principles and functions to meet project mission needs, including the following:

- Requirements-driven design, which incorporates safety objectives

- $\quad$ Configuration management

- Safety evaluation throughout the design process

- $\quad$ Compliance with DOE orders, guides, and manuals

- $\quad$ Requirements and functional analysis

- System integration

- $\quad$ Reliability objectives and management

- $\quad$ Risk analysis

- Integration of operating and maintenance procedures with the design effort through concurrent engineering or safety design integration team approaches

- $\quad$ Aggressive and integrated test and acceptance programs that incorporate safety concerns.

\section{SAFETY DESIGN STRATEGY}

Figure 2 shows the proposed CD milestone process as planned for the Remote-Handled LLW Disposal Project.

Life-cycle phases for the Remote-Handled LLW Disposal Project are described in the following subsections. The project will be conducted in accordance with the project management requirements of DOE Order 413.3A. Because of the maturity of the requirements, the lack of complexity, and the cost and schedule knowledge gained from ongoing remote-handled LLW disposal operations at INL, a combined CD-2/3A package will be developed for the project, and a design-build project delivery method will be used.

\subsection{Life-Cycle Phases}

- $\quad$ Preconceptual Phase. This phase led to the formal start of the project through identification of a project need and approval of mission need documentation.

- Conceptual Phase. This initial design phase involves development of a conceptual design report and other documents. CD-1 is the end point of this phase and is culminated by approval of the preliminary project baseline.

- Performance Baseline Phase. Activities in this phase are dedicated to the establishment of a project baseline, including mutually dependent technical, schedule, and cost components, and with development of detailed system requirements defined in the design-build performance specification. The PDSA also will be developed during this phase. The project baseline will be reviewed and approved at $\mathrm{CD}-2 / 3 \mathrm{~A}$ before initiation of the execution phase. 


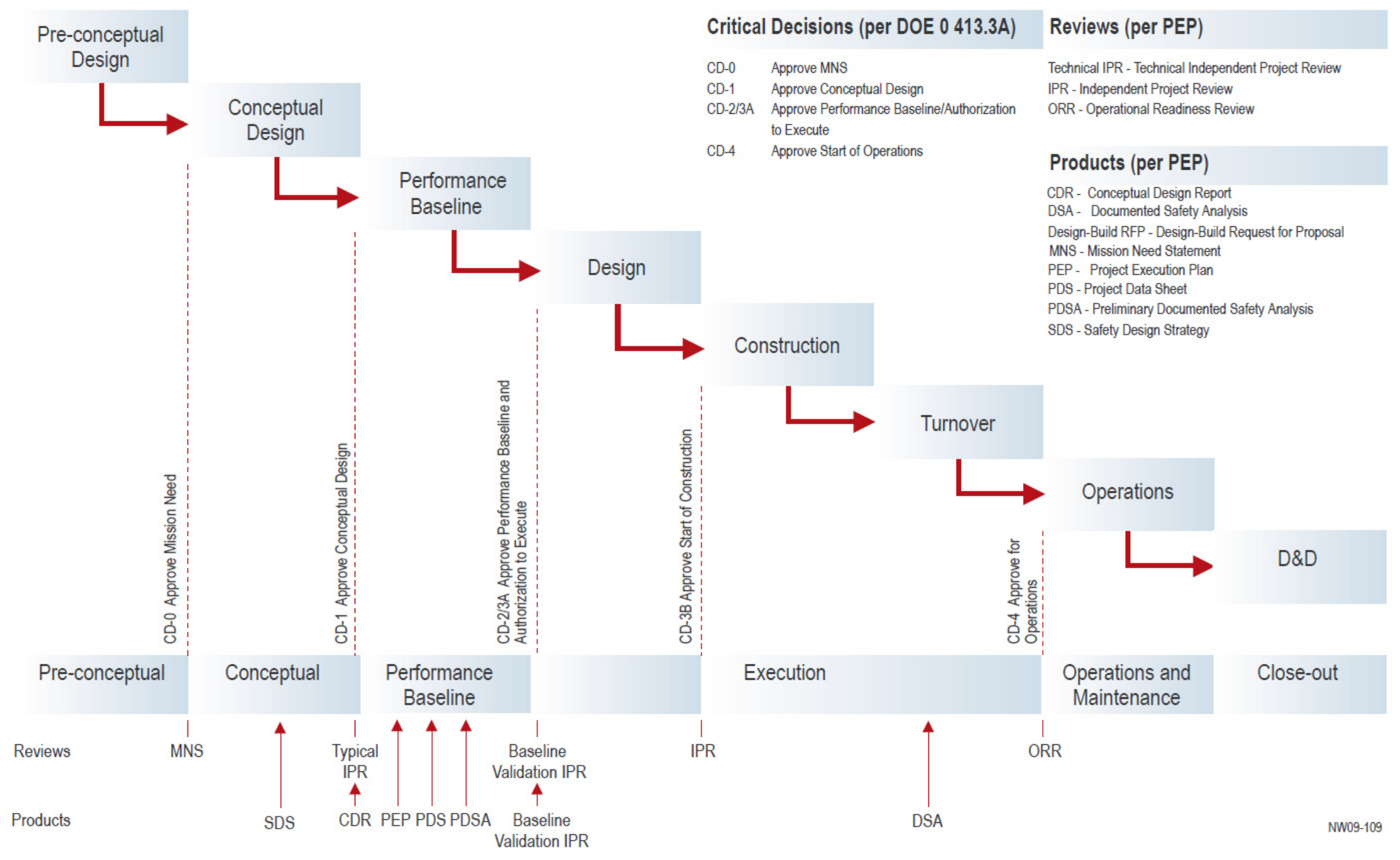

Figure 2. Project life cycle tailored to a design-build project delivery method. 
The systems engineering process in this stage (pre-CD-2/3A) will focus on development of the initial baselines, safety and hazard evaluation, identification and definition of work efforts and associated schedules, and synthesis of the project. The project team will subsequently (1) identify the specific resources and other project planning products that will be required to accomplish project objectives, and (2) establish the scope, schedule, and cost for the project. The project team also will develop the project data sheet and design-build performance specification.

- $\quad$ Execution Phase. Design and construction of the new remote-handled LLW disposal facility will be accomplished using a design-build project delivery method. During this phase, the design-build contract will be competitively bid to qualified general construction subcontractors. A firm, fixed-priced contract with fixed milestone completion dates will be used. The request for proposal will be sent to qualified general construction companies responsible for both design and construction activities. The project documented safety analysis (DSA) will be developed and responses to the request for proposal will be evaluated during this phase, which begins at CD-2/3A and culminates at CD-4. The final step in the execution phase is the operational readiness review.

- $\quad$ Operations and Maintenance Phase. The operations and maintenance phase of the project life cycle will be carried out by the Operations and Maintenance organization, following acceptance and turnover from the project. While this phase is not under the purview of the project, the needs of the operations and maintenance phase will be incorporated into requirements analysis, procedure and operations planning, and life-cycle analysis activities (e.g., operations funding and maintenance funding requirements) during the execution phase.

- Closeout Phase. The closeout phase of the project life cycle will be carried out by the Decontamination and Decommissioning organization following completion of operations and maintenance activities. While decontamination and decommissioning is not under the purview of the project, decontamination and decommissioning requirements will be addressed in project and facility life-cycle planning efforts (e.g., vault maintenance and closure requirements and long-term monitoring requirements).

\subsection{Safety Guidance and Requirements}

Conceptual design for the new remote-handled LLW disposal facility is substantially based on the existing concrete disposal vaults in the SDA. In addition to providing for operational efficiencies, reliance on the existing design provides a fundamental basis for implementation of safety requirements for the new disposal facility. The basic design of the facility and corresponding operations activities consider the high radiation levels associated with the remote-handled LLW stream and minimize worker radiological exposure. The major facility components, as described in the Conceptual Design Report (INL 2009b), are the vaults, vault plugs, and cask-to-vault adapting structure. These components, coupled with the generator shipping casks and waste liners, provide for passive control of worker radiological exposure.

The design and safety evaluation will be completed in accordance with DOE-STD-1189-2008. However, a tailored approach will be used where known facility hazards from the existing RWMC remote-handled LLW disposal facility will be used as the primary hazard analysis, allowing a direct move to development of the PDSA and DSA. Because of the fact that there are relatively no inherent hazards with confinement, ventilation, fire, or seismic releases, the associated hazards for this facility will be few and result in low hazard accident scenarios, as addressed in the project preliminary hazards assessment (INL 2009a). A detailed hazard review will be performed during the design phase, which will entail a detailed review and incorporation of the existing facility operations and hazards. Because of the use of a proven design and the fact that operations are currently ongoing that address the associated hazards, this 
project can proceed directly to the development of the PDSA during the CD-2/3A timeframe. Development of the DSA will be completed during the CD-4 (or execution) timeframe.

The facility will be designed and operated in accordance with the requirements, codes, and standards identified in Section 3.1.4 of TFR-483, including DOE Order 420.1B. Hazards posed by the facility will be identified by examining the following:

- Quantity, form, and location of radioactive and hazardous materials that are potentially releasable from the remote-handled LLW disposal facility

- $\quad$ Potential energy sources and initiating events that could directly result in injury to workers or lead to a release of radioactive or hazardous materials.

In accordance with Section C.2.4.B of the INL contract (INL 2004), DOE's safety expectations of the INL contractor are as follows:

1. Establish clear safety, environmental protection, health, and quality assurance priorities and manage activities consistent with those priorities

2. Use a graded approach to the program and project safety integration process

3. Have an effective employee involvement program

4. Maintain an effective Integrated Safety Management System.

The specific requirement related to management of INL remote-handled waste is delineated in Part III, Section J, Attachment P of the INL contract (INL 2004), which states:

The INL Contractor shall manage INL generated $L L W$ and, if directed by DOE, $L L W$ generated by other tenants (e.g., NRF) upon closure of the RWMC LLW disposal operations...LLW management includes development of on/offsite LLW disposal capability and the supporting infrastructure.

DOE expects the INL contractor to manage remote-handled LLW in a manner that is protective of both human health and the environment.

\subsection{Hazard Identification}

The project's preliminary hazards analysis (INL 2009a) identifies potential hazards for processes associated with handling and disposing of remote-handled LLW at the new disposal facility. Hazardous material inventories for construction and operation of the remote-handled LLW disposal facility are very low in comparison to other nuclear operations and are commensurate with existing RWMC remote-handled LLW disposal operations. No chemicals found in the Occupational Safety and Health Administration substance-specific standards have been identified that would create a potential for exposure triggering medical surveillance during construction or operations. Additionally, no highly hazardous chemicals listed in 29 CFR 1910.119, "Process Safety Management of Highly Hazardous Chemicals (Appendix A, List of Highly Hazardous Chemicals, or Toxics and Reactives)," will be generated, used, stored, or disposed of at this facility. The primary hazard associated with the facility is worker exposure to the high radiation levels associated with the waste through a variety of exposure scenarios. 


\subsubsection{Hazard Analysis and Classification}

With respect to nuclear safety, a hazard is defined as "a source of danger (i.e., material, energy source, or operation) with the potential to cause illness, injury, or death to personnel or damage to an operation or to the environment (without regard for the likelihood or credibility of accident scenarios or consequence mitigation)." To identify potential facility hazards, the following were examined:

- $\quad$ The material at risk (i.e., quantity, form, and location of radioactive and hazardous materials) that is potentially releasable from the remote-handled LLW facility

- $\quad$ Potential energy sources and potential initiating events that could directly result in injury to workers or lead to release of radioactive or hazardous materials.

Based on the preliminary hazards analysis and comparison with DOE-STD-1027-92, "Hazard Categorization and Accident Analysis Techniques for Compliance with DOE Order 5480.23, Nuclear Safety Analysis Reports," the Remote-Handled LLW Disposal Project has been determined to be a Hazard Category 2 nuclear facility. This position will be further evaluated by the INL contractor in the future PDSA and DSA per NS-18101, "INL Safety Analysis Process." The PDSA will be prepared as the design is finalized by a qualified nuclear safety analyst, as defined in accordance with NS-18309, "INL Safety Analyst Qualification." Development of the PDSA will provide detailed evaluations of all applicable hazards and, through thorough review and comment from both INL and DOE, will be used for development and approval of the final, approved DSA for the remote-handled LLW disposal facility.

\subsubsection{Performance Category}

Based on a comparison of the remote-handled LLW disposal project's proposed operations and evaluating these operations against the guidance provided in DOE-STD-1021-39A, "Natural Phenomena Hazards Performance Categorization Guidelines for Structures, Systems, and Components," Section 2.4, a preliminary Performance Category 1 designation was assigned to the planned disposal facility. This designation is equivalent to a Seismic Design Category 2 when using the design basis earthquake evaluation criteria specified in American National Standards Institute/American Nuclear Society 2.26 and American Society of Civil Engineers/Structural Engineering Institute 43-05, which are implemented by DOE-STD-1189-2008. The basis for this designation is as follows:

- The only components of the remote-handled LLW disposal project that are related to safety are the precast concrete disposal vaults. However, they are not considered to be "safety significant"

- $\quad$ The vaults are located below ground surface, isolating contents from facility workers, and, upon failure, will not impose any risk of fatality or serious injury to workers

- $\quad$ There are no failure scenarios for the vaults that result in a loss of function in an emergency system that may be needed to preserve the health and safety of workers and visitors

- In the improbable event of vault failure, there would be no offsite consequences of note

- $\quad$ Support facilities (i.e., maintenance and administrative structures) that may be co-located and designed for human occupancy, will not be used or directly associated with placement and handling of the actual LLW materials or disposal operations 
- In the unlikely event of vault failure before filling capacity, the only impact would be related to a decrease in the overall capacity of the remote-handled LLW disposal facility. This could require installation of additional vaults to recover the lost volume capacity.

Further in-depth analysis regarding the seismic design category will be completed and documented in the project safety basis documents in accordance with NS-18101. A comprehensive seismic analysis will be required to evaluate the imposed natural phenomenon hazard associated with the specific site location, facility configuration, and operational approach. This analysis will be completed in accordance with the International Building Code practices for a similar type facility.

\subsubsection{Emergency Preparedness}

The INL Emergency Management Department plans and implements a compliant, proactive, risk-based program developed to respond to and mitigate consequences of emergencies that may arise at INL. Emergency Management's core planning and readiness assurance functions include the following:

- $\quad$ Determining hazards and credible events that could result in emergency situations

- Preparing for those situations through development of a trained Emergency Response organization

- $\quad$ Procuring and maintaining emergency equipment and facilities

- $\quad$ Determining protective actions

- Developing standards and techniques for notifications, categorization/classification, consequence assessment, reentry, medical support, and program administration

- $\quad$ Providing timely and accurate public information

- $\quad$ Identifying the diverse elements involved in recovery and reentry.

Activities associated with the remote-handled LLW disposal project will be included within the framework of INL's existing Emergency Management System.

\subsubsection{Criticality}

Waste streams, as received, are remote-handled LLW and contain less than $10 \mathrm{nCi} / \mathrm{g}$ of transuranic isotopes and little fissile material. The INL and NRF remote-handled LLW waste forms present no risk of criticality.

\subsubsection{Facility, Structures, Systems, and Component Functions}

The proposed remote-handled LLW disposal facility will be designed and constructed similar to the remote handled LLW concrete disposal vaults currently in use in the SDA. This will accommodate, to the maximum extent possible, uninterrupted operations at the generating facilities and will capitalize on the operations experience and cost efficiencies of current remote handled LLW disposal practices. The vaults will be constructed of precast concrete cylinders (i.e., pipe sections) stacked on end and placed in a honeycomb-type array (see Figure 3). A removable concrete plug will be set on top of the stacked cylinders to serve as a radiation shield and water barrier. 


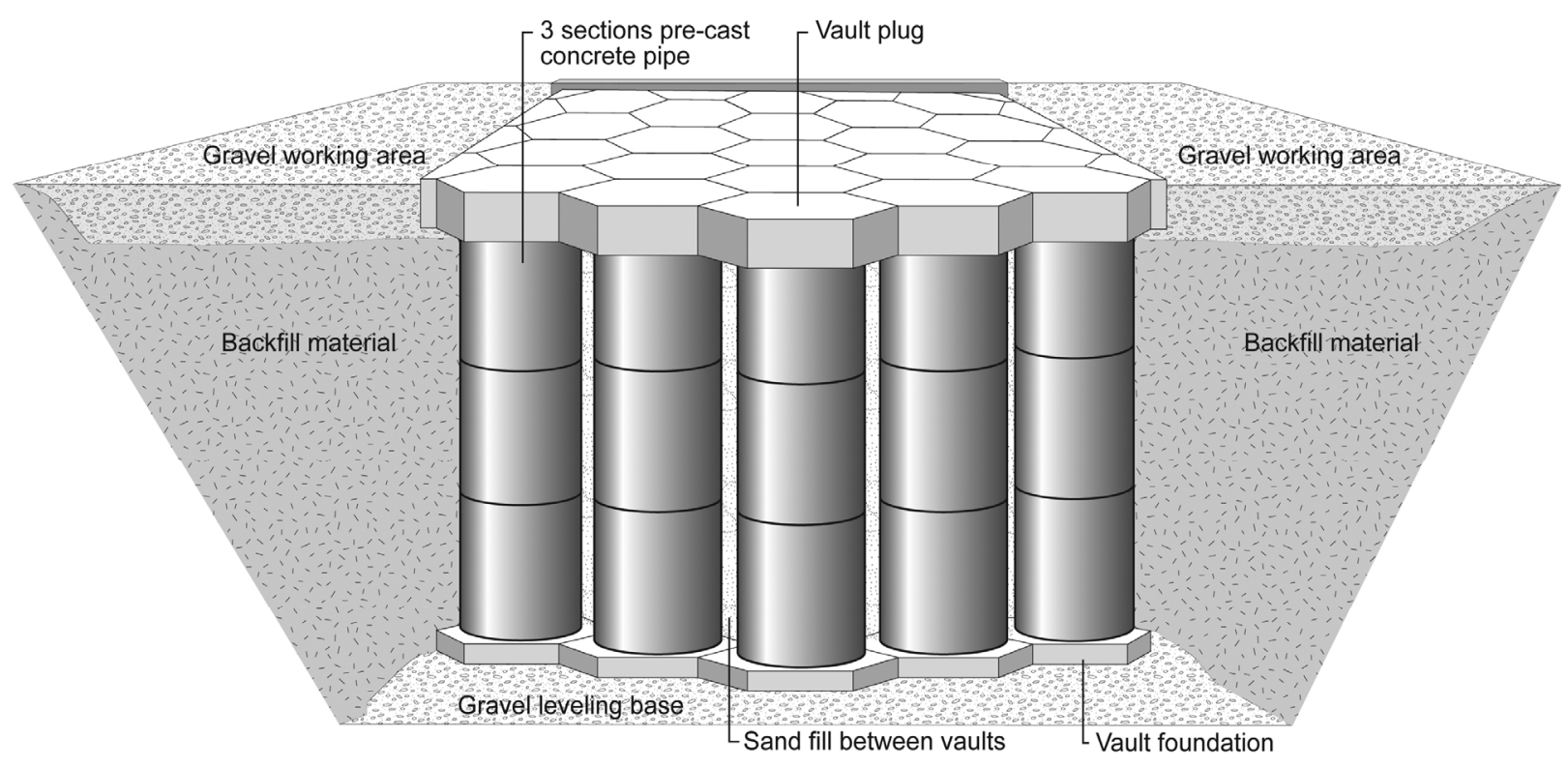

Figure 3. Concrete vault layout.

\subsubsection{Operational Overview}

Remote-handled LLW destined for disposal will be packaged into shielded casks with waste liners. The liners will normally consist of cylindrical containers designed specifically for the cask systems used. It is assumed that remote-handled LLW will be transported from NRF to the new disposal facility in the same 55-ton scrap cask that is currently used at RWMC. The operational system associated with the cask and transfer system used by other INL generators will be determined once specific liner designs and cask systems are identified; however, operations will be substantially the same as those required for handling the NRF 55-ton scrap cask.

\subsubsection{Anticipated Waste Streams}

The anticipated waste for this project consists of remote-handled LLW, nonhazardous activated metals, and resins with external radiation fields that range from $200 \mathrm{mR} / \mathrm{hr}$ up to $30,000 \mathrm{R} / \mathrm{hr}$. A complete description of the waste from each generating facility and waste stream characterization data are provided in the Low-Level Waste Disposal Alternatives Analysis Report (INL 2006, Appendix B) and the respective INL Integrated Waste Tracking System material profiles (No. 2312A.R2 and No. 2534). It is expected that the radionuclide inventory in this waste stream warrants the Facility Hazard Categorization 2 designation.

\subsubsection{Facility Description}

Facility configuration for the new remote-handled LLW disposal facility is similar to the existing vault design and configuration that is currently present at RWMC. The facility includes concrete vaults, vault plugs, access roads, and support infrastructure. Figure 4 shows the proposed layout for the disposal facility.

The facility layout is based on the assumption that the facility that will be constructed and operated will be a stand-alone facility and will provide its own administration buildings and infrastructure to support disposal operations. If a facility site is selected that is located in the vicinity of an existing facility, where existing buildings may be utilized, then new construction of some of the infrastructure components may not be needed (i.e., the administration building). 


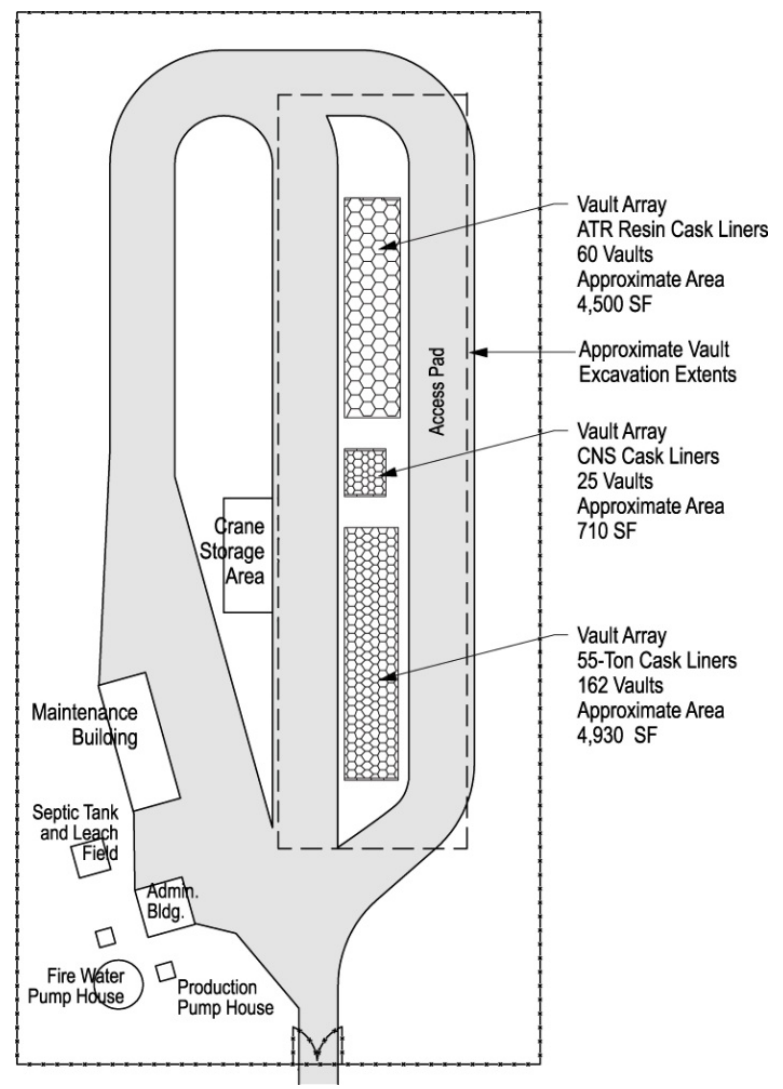

Figure 4. Proposed layout for the remote-handled low-level waste disposal facility.

3.3.8.1 Facility Radioactive Material Evaluation. Operationally, the proposed facility is designed to accept shipments of remote-handled LLW (including activated metals and resins) from NRF, the Advanced Test Reactor, and other INL generators. The total remote-handled LLW disposal project radioactive material inventory anticipated to be present in the facility at a given time will exceed the Hazard Category 2 threshold quantities values for several radionuclides per DOE-STD-1027-92. Based on the initial facility determination and in accordance with LWP-18002, "INL Facility Categorization," and DOE-STD-1027-92, the remote-handled LLW disposal facility will be a Hazard Category 2 facility.

While it is likely that no single radionuclide in a single waste container exceeds the associated DOE-STD-1027-92 Hazard Category 2 (Table A.1) threshold quantities values, the summation of waste containers or cumulative facility inventory of radionuclide activity-to-Hazard Category 2 threshold quantities values ratios warrants the Hazard Category 2 designation. Alternative Hazard Category 2 threshold quantities values for radionuclides not found in DOE-STD-1027-92 are listed in Los Alamos National Laboratory Fact Sheet LA-12846-MS, Specific Activities and DOE-STD-1027-92 Hazard Category 2 Thresholds (LANL 1994), and were considered in this determination.

Classifying the disposal facility as Hazard Category 2 will be further evaluated by INL in the PDSA and DSA as required per NS-18101. The PDSA will be prepared by a qualified nuclear safety analyst (as defined in accordance with NS-18309) as the design finalizes. Development of the PDSA will provide detailed evaluations of all applicable hazards and, through thorough review and comment from both INL and DOE, will be used for development and approval of the final, approved DSA for the remote-handled LLW disposal project. 


\subsubsection{Identification of Primary Facility Hazards}

From review of the facility conceptual design report and previous lessons learned, an analysis for potential hazards was performed. The result of this analysis is found in Table 1, which represents hazards and initiators that should be considered as the design progresses and the safety basis documentation is being prepared. This table, which lists identified hazards, causes of the hazards, and possible preventative and mitigative responses, is not intended to be all inclusive and may be updated, as required.

As the project design matures, generation of other safety documents and analyses will be required. These supporting documents, other than operational procedures, will include the following as appropriate:

- $\quad$ Fire hazard analysis

- $\quad$ Fire safety assessments

- $\quad$ PDSA

- $\quad$ DSA (DOE approval required) to supplement INL's standardized DSA

- Hoisting and rigging plan

- $\quad$ Engineering design files

- As low as reasonably achievable reviews

- $\quad$ Radiation work permits

- $\quad$ Operational job safety analyses

- Industrial hygiene exposure assessments prepared in accordance with the associated INL procedures.

\subsection{Key Safety Decisions}

Decisions will be made throughout the project life cycle that will affect the eventual design and construction of a new disposal facility for remote-handled LLW at INL. CD points are shown in Figure 2 in relation to the life-cycle activities to which they apply. Exit criteria will be defined as a part of the detailed planning for the technical reviews associated with each CD. This project will apply a tailored approach in complying with DOE Order 413.3A.

\subsubsection{Approve Mission Need (CD-0)}

Approval of mission need was received on July 1, 2009.

\subsubsection{Preliminary Baseline (CD-1)}

The CD-1 request for approval of the preliminary project baseline will be based on documents developed during this phase, including a conceptual design report, this SDS, an acquisition strategy, and a project execution plan. 
Table 1. Preliminary hazards identified for the remote-handled low-level waste disposal project.

\begin{tabular}{|c|c|c|c|c|c|c|}
\hline Hazard & Initiator & Location & Operation & Possible Consequences & Preventive Features & Mitigative Features \\
\hline $\begin{array}{l}\text { Remote- } \\
\text { handled } \\
\text { waste }\end{array}$ & $\begin{array}{l}\text { Transfer cask } \\
\text { drop }\end{array}$ & $\begin{array}{l}\text { Facility } \\
\text { roadway } \\
\text { Storage } \\
\text { vault array } \\
\text { location } \\
\end{array}$ & $\begin{array}{l}\text { Entry of truck } \\
\text { or forklift to } \\
\text { disposal area } \\
\text { Crane } \\
\text { operations } \\
\end{array}$ & $\begin{array}{l}\text { Damage to cask and } \\
\text { release of radiological } \\
\text { material }\end{array}$ & $\begin{array}{l}\text { Employee training } \\
\text { Equipment inspection and } \\
\text { maintenance programs } \\
\text { Control vehicle speed } \\
\text { Hoisting and rigging program }\end{array}$ & $\begin{array}{l}\text { Solid waste form } \\
\text { Robust transfer cask }\end{array}$ \\
\hline $\begin{array}{l}\text { Remote- } \\
\text { handled } \\
\text { waste }\end{array}$ & $\begin{array}{l}\text { Inner waste } \\
\text { liner drop and } \\
\text { breach }\end{array}$ & $\begin{array}{l}\text { Storage } \\
\text { vault array }\end{array}$ & $\begin{array}{l}\text { Remote- } \\
\text { handled waste } \\
\text { transfer }\end{array}$ & $\begin{array}{l}\text { Damage to inner waste } \\
\text { liner and release of } \\
\text { radiological material }\end{array}$ & $\begin{array}{l}\text { Employee training } \\
\text { Equipment inspection and } \\
\text { maintenance programs } \\
\text { Hoisting and rigging program }\end{array}$ & $\begin{array}{l}\text { Solid waste form } \\
\text { Waste liner integrity }\end{array}$ \\
\hline $\begin{array}{l}\text { Remote- } \\
\text { handled } \\
\text { waste }\end{array}$ & $\begin{array}{l}\text { Transfer cask } \\
\text { drop }\end{array}$ & $\begin{array}{l}\text { Facility } \\
\text { roadway } \\
\text { Storage } \\
\text { vault array } \\
\text { location } \\
\end{array}$ & $\begin{array}{l}\text { Entry of truck } \\
\text { or forklift to } \\
\text { disposal area } \\
\text { Crane } \\
\text { operations } \\
\end{array}$ & $\begin{array}{l}\text { Damage to cask and } \\
\text { loss of shielding, } \\
\text { resulting in a direct } \\
\text { radiation exposure } \\
\text { hazard }\end{array}$ & $\begin{array}{l}\text { Employee training } \\
\text { Equipment inspection and } \\
\text { maintenance programs } \\
\text { Control vehicle speed } \\
\text { Hoisting and rigging program }\end{array}$ & $\begin{array}{l}\text { Immediate worker evacuation } \\
\text { Robust transfer cask }\end{array}$ \\
\hline $\begin{array}{l}\text { Remote- } \\
\text { handled } \\
\text { waste }\end{array}$ & $\begin{array}{l}\text { Corrosion } \\
\text { induced } \\
\text { waste liner } \\
\text { failure }\end{array}$ & $\begin{array}{l}\text { Storage } \\
\text { vault array }\end{array}$ & $\begin{array}{l}\text { Passive vault } \\
\text { storage }\end{array}$ & No anticipated release & $\begin{array}{l}\text { Surveillance program } \\
\text { Facility design }\end{array}$ & $\begin{array}{l}\text { Vault storage completely } \\
\text { enclosed underground } \\
\text { Vault storage designed to } \\
\text { minimize potential water } \\
\text { infiltration }\end{array}$ \\
\hline $\begin{array}{l}\text { Remote- } \\
\text { handled } \\
\text { waste }\end{array}$ & $\begin{array}{l}\text { Natural } \\
\text { phenomena } \\
\text { hazards } \\
\text { (e.g., tornado, } \\
\text { flood, range } \\
\text { fire, } \\
\text { lightning, or } \\
\text { volcanoes) }\end{array}$ & $\begin{array}{l}\text { Storage } \\
\text { vault array }\end{array}$ & $\begin{array}{l}\text { Passive vault } \\
\text { storage }\end{array}$ & No anticipated release & Facility design & $\begin{array}{l}\text { Vault storage completely } \\
\text { enclosed underground } \\
\text { Appropriate facility siting }\end{array}$ \\
\hline
\end{tabular}


Table 1. (continued).

\begin{tabular}{|c|c|c|c|c|c|c|}
\hline Hazard & Initiator & Location & Operation & Possible Consequences & Preventive Features & Mitigative Features \\
\hline $\begin{array}{l}\text { Remote- } \\
\text { handled } \\
\text { waste }\end{array}$ & $\begin{array}{l}\text { External } \\
\text { events } \\
\text { (e.g., plane } \\
\text { crash, vehicle } \\
\text { crash, or } \\
\text { adjacent } \\
\text { building fire/ } \\
\text { explosion) }\end{array}$ & $\begin{array}{l}\text { Storage } \\
\text { vault array }\end{array}$ & $\begin{array}{l}\text { Passive vault } \\
\text { storage }\end{array}$ & No anticipated release & Facility design & $\begin{array}{l}\text { Vault storage completely } \\
\text { enclosed underground } \\
\text { Appropriate facility siting }\end{array}$ \\
\hline $\begin{array}{l}\text { Combustible } \\
\text { remote- } \\
\text { handled } \\
\text { waste }\end{array}$ & $\begin{array}{l}\text { Transfer } \\
\text { vehicle fire } \\
\text { resulting in } \\
\text { cask/ } \\
\text { container } \\
\text { failure }\end{array}$ & $\begin{array}{l}\text { Facility } \\
\text { roadway }\end{array}$ & $\begin{array}{l}\text { Entry of truck } \\
\text { or forklift into } \\
\text { the disposal } \\
\text { area }\end{array}$ & $\begin{array}{l}\text { Damage to cask or } \\
\text { waste container, } \\
\text { resulting in release and } \\
\text { dispersal of radiological } \\
\text { material }\end{array}$ & $\begin{array}{l}\text { Employee training } \\
\text { Equipment maintenance and } \\
\text { inspection } \\
\text { Robust casks and waste } \\
\text { containers function as fire } \\
\text { barrier }\end{array}$ & $\begin{array}{l}\text { Facility fire suppression } \\
\text { system } \\
\text { INL fire department response }\end{array}$ \\
\hline $\begin{array}{l}\text { Combustible } \\
\text { remote- } \\
\text { handled } \\
\text { waste }\end{array}$ & $\begin{array}{l}\text { Waste } \\
\text { container } \\
\text { drop resulting } \\
\text { in container } \\
\text { breach and } \\
\text { fire }\end{array}$ & $\begin{array}{l}\text { Storage } \\
\text { vault array }\end{array}$ & $\begin{array}{l}\text { Crane } \\
\text { operation, } \\
\text { including } \\
\text { waste } \\
\text { container } \\
\text { placement }\end{array}$ & $\begin{array}{l}\text { Damage to waste } \\
\text { container, resulting in } \\
\text { release and dispersal of } \\
\text { radiological material }\end{array}$ & $\begin{array}{l}\text { Employee training } \\
\text { Equipment maintenance and } \\
\text { inspection } \\
\text { Robust waste containers } \\
\text { function as fire barrier }\end{array}$ & $\begin{array}{l}\text { Suppression system } \\
\text { INL fire department response }\end{array}$ \\
\hline $\begin{array}{l}\text { Remote- } \\
\text { handled } \\
\text { waste }\end{array}$ & $\begin{array}{l}\text { Loss of shield } \\
\text { plug integrity }\end{array}$ & $\begin{array}{l}\text { Storage } \\
\text { vault array }\end{array}$ & $\begin{array}{l}\text { Passive vault } \\
\text { storage }\end{array}$ & $\begin{array}{l}\text { Direct radiation } \\
\text { exposure to workers }\end{array}$ & $\begin{array}{l}\text { Robust shield plug design } \\
\text { Surveillance program }\end{array}$ & $\begin{array}{l}\text { Immediate worker evacuation } \\
\text { Emergency response } \\
\text { procedures }\end{array}$ \\
\hline
\end{tabular}




\subsubsection{Approve Performance Baseline and Authorization to Execute (CD-2/3A)}

The project will seek approval of a tailored, combined CD-2 and CD-3A (resulting in CD-2/3A) request consistent with a design-build project delivery method. The design-build contract request for proposal will be issued following DOE approval to support contract award in the first quarter of 2012, with a construction completion date of the fourth quarter of 2014. CD-2/3A formally defines the initial scope, schedule, and cost elements of the project baseline as the basis for measuring the progress of the project and evaluating the effectiveness of management systems. Alternative trade-off studies will have been completed, the functional and operational requirements identified and developed into the final design criteria, and the performance baseline established. All safety-related information will be documented in the PDSA.

\subsubsection{Approve Start of Construction (CD-3B)}

This decision will occur before start of construction and following completion of final design. Appropriate revisions to the alternatives trade-off studies will have already been completed to support the final design decisions. A final design is established at the end of the design portion of the execution phase. The final design is reviewed in the independent project review to confirm construction readiness.

\subsubsection{Approve Start of Operations (CD-4)}

This decision will occur before start of operations. The final as-built design will have been documented as part of the project record. Operations may not start until the operational readiness review has been successfully conducted. The as-built baseline is established at the end of the construction portion of the execution phase. The as-built baseline confirms that the facility conforms "as built" to the specifications. The as-built baseline may be further updated during the operations and maintenance phase in response to operational modifications.

In addition to ensuring compliance with the requirements of DOE Order 5400.5, "Radiation Protection of the Public and the Environment," other key safety aspects associated with the INL Remote-Handled LLW Disposal Project include compliance with applicable seismic requirements, compliance with the performance objectives of DOE Order 435.1, "Radioactive Waste Management," and criticality safety.

Based on a comparison of the remote-handled LLW disposal facility's proposed operations and an evaluation of these operations against the guidance provided in DOE-STD-1021-39, Section 2.4, a preliminary Performance Category 1 designation has been assigned to the project. The basis for this designation is documented in Section 7.2 of the conceptual design report (INL 2009b) and will be validated prior to CD-2/3A. The designation is expected to be equivalent to a Seismic Design Category of 2 if the requirements of DOE-STD-1189 are implemented for the project. This categorization is appropriate based on assumptions that the vaults will not be used as a protective or confining barrier; no personnel will ever enter the vaults and, therefore, have no ventilation requirement; and that no personnel radioactive exposure will result if a vault is broken or damaged. The primary purpose of the vaults is to provide access to the subsurface for efficient placement of waste liners. Based on the configuration of the vaults, as presented in the conceptual design report, no aboveground or other occupied structures would be directly impacted as a result of vault failure related to a seismic event. As the design for the facility is finalized, the site for its location identified, and the operational approach definitized (based on current processes), further seismic analysis will be required. A comprehensive seismic analysis, due to the natural phenomenon hazard, will be completed in accordance with the International Building Code practices for Group 1 facilities. 
Other natural hazard phenomena (e.g., flooding and volcanic eruption) will be minimized, to the extent possible, through establishment of siting criteria. Upon selection of a specific location for the new disposal facility, these phenomena will be explored in more detail in relation to the specific onsite location of the facility.

The impact of a potential release from the facility will be evaluated in accordance with DOE Order 435.1. A radiological performance assessment and composite analysis will be prepared to demonstrate that there is a reasonable expectation that the following performance objectives will be met:

- Dose to representative members of the public will not exceed $25 \mathrm{mR}(0.25 \mathrm{mSv})$ in a year total effective dose equivalent from all exposure pathways, excluding dose from radon and its progeny in air

- Dose to representative members of the public via the air pathway will not exceed $10 \mathrm{mR}$ $(0.10 \mathrm{mSv})$ in a year total effective dose equivalent, excluding the dose from radon and its progeny

- $\quad$ Release of radon will be less than an average flux of $20 \mathrm{pCi} / \mathrm{m} 2 / \mathrm{s}(0.74 \mathrm{~Bq} / \mathrm{m} 2 / \mathrm{s})$ at the surface of the disposal facility. Alternatively, a limit of $0.5 \mathrm{pCi} / 1(0.0185 \mathrm{~Bq} / \mathrm{l})$ of air may be applied at the boundary of the facility.

The resulting DOE headquarters-issued disposal authorization statement will specify limits and conditions on construction, design, operations, and closure of the LLW disposal facility, and the hazards will be addressed in the DSA.

\section{RISKS TO PROJECT SAFETY DECISIONS}

Because the new disposal facility is being planned substantially based on the existing disposal facility design and operations, and as no significant changes to the remote-handled waste characteristics are anticipated, the most significant project safety risk relates to implementation of the newly released DOE-STD-1189-2008. Cost and schedule impacts associated with INL implementation of the new standard have not yet been fully assessed. Risks associated with implementation of DOE-STD-1189-2008 are identified in the project risk management plan (PLN-2541). As the project develops, the risks associated with implementation of DOE-STD-1189-2008 will be better defined and quantified. Impacts to project cost and schedule, if any, will be incorporated into the project performance baseline established as part of CD-2/3A approval. Although the cost and schedule impacts associated with implementation are not fully known at this time, other project risks that could have a more significant impact on the project.

\section{SAFETY ANALYSIS APPROACH AND PLAN}

As a Hazard Category 2 nuclear facility, the disposal facility must meet specified nuclear safety requirements. The requisite nuclear safety documentation will be developed as part of the project. Such documentation includes a conceptual safety design report, a preliminary hazard analysis report, a preliminary safety validation report, a preliminary safety design report, a hazard analysis report, a preliminary safety validation report, the PDSA report, the DSA, and the safety evaluation report. DOE-STD-1189-2008 provides implementation guidance for Hazard Category 1, 2, and 3 nuclear facilities safety requirements.

The project is following the requirements of DOE Order 413.3A to the extent practical. As such, the nuclear safety documentation identified above may be combined as part of tailoring for the project. Specifically, the project preliminary hazards analysis (INL 2009a) is being coupled with the existing safety analysis report for RWMC (SAR-4) to meet the CD-1 requirement for a conceptual safety design 
report. Because the new disposal facility is being planned substantially based on the existing disposal vaults in the SDA, safety documentation for the SDA is bounding for planned operations at the new disposal facility. Safety documentation associated with the SDA is considered bounding for several reasons as follows:

- SDA disposal activities encompass a wider range of radioactive waste management activities (i.e., open pit disposal) than is planned for the new disposal facility.

- $\quad$ SDA disposal activities are conducted in an area with historical radiological and chemical contamination associated with past disposal practices; siting of the new disposal facility will minimize, to the extent possible, locating the facility within a contaminated area.

- Waste management activities in the SDA include both waste disposal and waste retrieval operations being conducted as part of a CERCLA removal action. Only remote-handled LLW disposal operations will be conducted at the new disposal facility.

- No significant changes to the remote-handled waste characteristics currently being managed in the SDA and that are planned for the new disposal facility are anticipated.

Project safety basis document preparation will follow the guidance of DOE-STD-1189-2008, which is to integrate safety analysis throughout the design process. The standard is intended to implement safety-in-design philosophies listed in DOE Order 413.3A and facility safety criteria listed in DOE Order 420.1B. The approach is intended to ensure that hazards are identified early in the project and that a safety design integration team approach is used to design safety into the facility.

\section{SAFETY DESIGN INTEGRATION TEAM - INTERFACES AND INTEGRATION}

The safety design integration team includes appropriate representatives from traditional worker safety disciplines, emergency management, and safeguards and security. The integrated project team consists of individuals representing diverse disciplines with specific areas of expertise and the ability to support the Federal Project Director in successful execution of the project. Membership may be full time or part time and will change as the project matures through the various phases from initiation through closeout. Membership will include federal and contractor employees and will consist of the members, or designees, defined in Table 2.

The responsibilities of the integrated project team include the following:

- $\quad$ Support the Federal Project Director

- $\quad$ Support preparation and submittal of funding request documents, as necessary, to secure project funding

- $\quad$ Support development of the project acquisition strategy

- $\quad$ Ensure interfaces are identified, defined, and managed to completion

- Identify and define and manage the implementation of environment, safety, health, and quality requirements

- Identify and define appropriate and adequate technical scope, schedule, and cost parameters 
- $\quad$ Perform periodic reviews and assessments of project performance, and status against established performance parameters, baselines, milestones, and deliverables

- $\quad$ Plan and participate in project reviews, audits, and appraisals, as necessary

- $\quad$ Review and comment on project deliverables, as appropriate

- $\quad$ Review change requests and support change control board actions, as appropriate

- $\quad$ Participate in readiness reviews or readiness assessments

- Support preparation, review, and approval of project completion and closeout documentation

- $\quad$ Ensure that safety is fully integrated into design, construction, and operations of the Hazard Category 2 nuclear facility.

Table 2. Remote-handled low-level waste disposal project safety design integration team.

\begin{tabular}{lll}
\multicolumn{1}{c}{ Organization } & \multicolumn{1}{c}{ Responsibility } & \multicolumn{1}{c}{ Member } \\
\hline DOE & Acquisition Executive, DOE NE-1 & Warren Miller \\
& NE-32 & Tracey Bishop \\
& Manager, DOE-ID & Dennis Miotla \\
& Deputy Manager-Nuclear Energy, DOE-ID & Raymond Furstenau \\
& Assistant Manager of Infrastructure, DOE-ID & William Hamel \\
INL Project & Federal Project Director, DOE-ID & Julie Conner \\
Office & Director & Robert Miklos \\
INL Project & Waste Programs Manager & Lisa Harvego \\
Support & Project Manager & Brady Orchard \\
& Systems Engineering & Danny Anderson \\
& Environmental Compliance & Timothy Carlson \\
& Nuclear Safety Engineering & Michael Lehto \\
& Occupational Safety and Health & Carolyn Mascarenas \\
& Project Engineering & TBD \\
& Procurement & TBD \\
& Planning and Financial Controls & Linda Hergesheimer \\
& Construction Services & Eric Anderson \\
& Construction Environment, Safety, and Health & TBD \\
& Quality Engineering & Leonard Stenzel/Evert Mouser \\
& Operations & TBD \\
& Point-of-Contact & Laura Hartman/Chris Henvit \\
\hline
\end{tabular}




\section{REFERENCES}

29 CFR 1910.119, "Process Safety Management of Highly Hazardous Chemicals (Appendix A, List of Highly Hazardous Chemicals, or Toxics and Reactives)," Code of Federal Regulations, Office of the Federal Register.

42 USC $§ 9601$ et seq., 1980, "Comprehensive Environmental Response, Compensation and Liability Act of 1980 (CERCLA/Superfund)," United States Code, December 11, 1980.

DOE Order 413.3A, "Program and Project Management for the Acquisition of Capital Assets," U.S. Department of Energy, July 2006.

DOE Order 420.1B, “Facility Safety,” U.S. Department of Energy, July 2004.

DOE Order 435.1, “Radioactive Waste Management,” U.S. Department of Energy, August 2001.

DOE Order 5400.5, "Radiation Protection of the Public and the Environment," U.S. Department of Energy, January 1993.

DOE Policy 450.4, “Integrated Safety Management Policy,” U.S. Department of Energy, October 2006.

DOE-STD-1021-39A, "Natural Phenomena Hazards Performance Categorization Guidelines for Structures, Systems, and Components,” U.S. Department of Energy, April 2002.

DOE-STD-1027-92, "Hazard Categorization and Accident Analysis Techniques for Compliance with DOE O 5480.23, Nuclear Safety Analysis Reports," U.S. Department of Energy, September 1997.

DOE-STD-1189-2008, "Integration of Safety into the Design Process,” U.S. Department of Energy, March 2008.

DOE-STD-3009-94, CN 3, "Preparation Guide for U.S. Department of Energy Nonreactor Nuclear Facility Safety Analysis,” U.S. Department of Energy, March 2006.

INL, 2004, "Management and Operation of the Idaho National Laboratory," Contract Number: DE-AC07-05ID14517, Idaho National Laboratory, Idaho Falls, Idaho, November 9, 2004.

INL, 2006, Low-Level Waste Disposal Alternatives Analysis Report, INL/EXT-06-11601, Idaho National Laboratory.

INL, 2009a, Preliminary Hazard Assessment for the Remote-Handled Low-Level Waste Disposal Facility, Idaho National Laboratory, Remote-Handled Low-Level Waste Disposal, INL/EXT-07-12903, Idaho National Laboratory, October 2009.

INL, 2009b, Conceptual Design Report for the Remote-Handled Low-Level Waste Disposal Project, Idaho National Laboratory, INL/EXT-07-12901, Idaho National Laboratory, October 2009.

LANL, 1994, Specific Activities and DOE-STD-1027-92 Hazard Category 2 Thresholds, Fact Sheet LA-12846, Los Alamos National Laboratory.

LWP-18002, "INL Facility Categorization,” Revision 1, Idaho National Laboratory, June 30, 2008. 
NS-18101, "INL Safety Analysis Process," Nuclear Safety, Revision 3, Idaho National Laboratory, May 6, 2008.

NS-18309, "INL Safety Analyst Qualification," Nuclear Safety, Revision 4, Idaho National Laboratory, May 14, 2009.

PLN-2541, "Risk Management Plan for the Remote-Handled Low-Level Waste Disposal Project," Revision 1, Idaho National Laboratory, October 2009. 